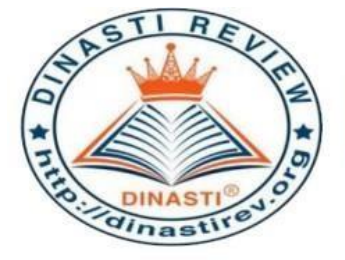

\title{
PELUANG DAN TANTANGAN UNTUK MANAJEMEN AKUNTANSI DI ERA BIG DATA
}

\section{Murbedi Aris Marico}

Universitas Mercu Buana, Jakarta

\begin{tabular}{|c|c|}
\hline $\begin{array}{l}\text { ARTICLE INFORMATION } \\
\text { Received: 01 September } 2019 \\
\text { Revised: } 11 \text { September } 2019 \\
\text { Issued: } 21 \text { September } 2019 \\
\text { Corresponding author: first author } \\
\text { E-mail: } \\
\text { my.manuscript01@gmail.com }\end{array}$ & $\begin{array}{l}\text { Abstrak: Perkembangan teknologi di masa depan saat } \\
\text { ini, khususnya teknologi komunikasi dan informasi } \\
\text { berbasis komputer, di mana andalan untuk teknologi } \\
\text { dan kebutuhan dunia .Hal ini disebabkan oleh } \\
\text { perkembangan sangat pesat pada teknologi komunikasi } \\
\text { dan komputer menyebabkan masyarakat dunia } \\
\text { melayang reformasi data dalam cepat, serta membuat } \\
\text { informasi sebagai pusat industri dan dunia usaha. } \\
\text { Teknologi informasi saat ini memiliki. pecah di } \\
\text { berbagai partiesWith teknologi informasi, jarak dan } \\
\text { waktu tidak lagi menjadi masalah yang harus } \\
\text { dipikirkan, karena informasi dapat diakses dari mana } \\
\text { saja dan kapan saja untuk berbagai belahan dunia } \\
\text { tetapi dalam pengguna teknologi seconds.Information } \\
\text { tidak perlu pergi ke negara tertentu untuk } \\
\text { mendapatkan. diperlukan informationUsing sebuah } \\
\text { komputer yang terhubung ke jaringan internet, semua } \\
\text { informasi, hiburan dan meskipun kita bisa melakukan. } \\
\text { perusahaan shoppingFor yang beroperasi di beberapa } \\
\text { lokasi dan memiliki pemasok dan konsumen yang } \\
\text { terpisah oleh jarak yang cukup jauh. Teknologi } \\
\text { informasi mampu mengintegrasikan, berkomunikasi } \\
\text { dan mempertukarkan kegiatan bisnis penting. } \\
\text { geografis distributedIn kata lain, jarak dan waktu } \\
\text { menjadi relatif dekat dan singkat. Saat ini teknologi } \\
\text { informasi untuk muncul dalam berbagai bentuk } \\
\text { teknologi .Information terintegrasi seperti internet, } \\
\text { groupware, perencanaan sumber daya perusahaan } \\
\text { (ERP) telah memperkuat fakta bahwa teknologi } \\
\text { informasi memiliki satu dengan dunia bisnis .Dalam } \\
\text { bidang akuntansi, sistem informasi pengolahan } \\
\text { akuntansi berbasis komputer telah diterapkan pada } \\
\text { organisasi untuk memberikan fasilitas bagi akuntan } \\
\text { dalam memproduksi informasi yang dapat digunakan } \\
\text { dalam pengambilan keputusan Jadi bahkan } \\
\text { mengatakan bahwa pemanfaatan teknologi informasi }\end{array}$ \\
\hline
\end{tabular}


pada setiap perusahaan yang beroperasi diperlukan untuk dihindari, digunakan untuk pengolahan data, dukungan pertukaran data dan informasi serta informasi yang cepat, tepat, dan akurat.

Kata Kunci: Akuntansi Manajemen, Peluang,

Tantangan.

\section{PENDAHULUAN}

Big teknologi data dan ide-ide di balik itu mengemudi perubahan besar dalam mode produksi dan hubungan. Hal ini juga mempromosikan reformasi mendalam dan leapfrogs pengembangan profesi akuntansi dan memberikan kesempatan langka untuk aplikasi akuntansi manajemen. Munculnya "Internet Plus" memberikan metode baru untuk akuisisi informasi dan pengolahan akuntansi manajemen, yang sangat memperkaya fungsi dan efisiensi manajemen akuntansi. [1] Internet aplikasi seperti komputasi awan dan Big Data telah hampir dibangun saluran digital antara perusahaan, dan membawa optimasi komprehensif dan peningkatan akuntansi manajemen yang meliputi model layanan, inovasi teknis, memilah data dan integrasi informasi.

Era Big Data memungkinkan untuk mengumpulkan preferensi konsumen, tren pasar, perusahaan produksi dan informasi operasi, dan untuk menyediakan perusahaan dengan jaminan informasi untuk penentuan posisi produksi dan jumlah pasokan ditentukan oleh permintaan. Di era Internet, pengumpulan data tidak masalah, dan perhatian manajer tidak hanya terbatas pada data terstruktur, tetapi juga untuk data yang tidak terstruktur. [2] Sebagai contoh, dalam akuntansi manajemen, tingkat pembelajaran dari balanced scorecard dalam evaluasi kinerja dan pengolahan data tidak terstruktur pada tingkat pelanggan mudah diperoleh, yang kondusif untuk pelaksanaan balanced scorecard. [3] Pada saat yang sama, aplikasi praktis dari statistik adalah kontra-produktif dengan balanced scorecard, yang menguntungkan pengembangan teori akuntansi manajemen. Kedatangan era "Internet Plus" tidak hanya mengubah konsep manajemen bisnis tetapi juga mempromosikan inovasi dan pengembangan akuntansi manajemen. Apakah itu adalah ABC, ABM, ABB atau balanced scorecard yang komprehensif, semua dasarnya menerobos sistem informasi bahwa akuntansi manajemen asli bergantung pada, dan lebih mementingkan sifat dari manajemen akuntansi manajemen dan pertambangan perusahaan bisnis manajemen informasi konotasi, sehingga dapat meningkatkan kualitas pengelolaan informasi akuntansi

\section{KAJIAN PUSTAKA}

Definision dari System Analyst, McLeod (2005) mengatakan bahwa, sistem adalah sekelompok terintegrasi dengan maksud yang sama untuk mencapai suatu tujuan. Jogiyanto HM berpendapat dalam memungkinkan untuk memiliki buku-buku mereka, adalah "diantisipasi bahwa analisis dan sistem informasi yang terintegrasi untuk termasuk pada jenis instrumen" 2001 yang analisis sistem nya adalah penguraian dari dari suatu sistem informasi yang terintegrasi untuk ukuran penuh satu panorama dari bagian - bagian komponennya dengan maksud untuk mengidentifikasi dan kebutuhan masalah evaluasi yang telah terjadi masalah yang telah terjadi, kemungkinan dan kesempatan, hambatan yang pecah dan kebutuhan untuk itu diharapkan agar dapat diusulkan untuk dipecahkan itu.

Selama analisis tahap sitem merujuk pada dasar yang harus dilakukan oleh analisis sistem sebagai berikut:

1) Mengenali 
2) Memahami

3) Menganalisa

4) Melaporkan.

\section{METODE PENELITIAN}

Untuk mendapatkan hasil yang optimal dan data yang akurat sehingga sebelum membuat penulis desain pendekatan dengan beberapa cara, sebagai berikut:

a. Pengamatan
b. Studi pustaka

\section{PEMBAHASAN}

\section{Kurangnya penekanan pada akuntansi manajemen}

Organisasi akuntansi kurang penekanan pada akuntansi manajemen. Pada manajemen perusahaan ini pengambil keputusan kurang memperhatikan dan penerapan akuntansi manajemen. akuntansi keuangan berfokus pada penyediaan informasi tentang status keuangan, hasil operasi dan arus kas perusahaan kepada stakeholder eksternal sementara akuntansi manajemen mendedikasikan untuk memberikan informasi tentang perencanaan manajemen, manajemen operasi dan keputusan peramalan untuk manajer internal perusahaan. Para pengambil keputusan bisnis penting melampirkan akuntansi manajemen langsung mempengaruhi penerapan akuntansi manajemen dalam perusahaan. Kurangnya pemahaman tentang akuntansi manajemen dalam pengambil keputusan bisnis secara langsung akan mempengaruhi penerapan akuntansi manajemen dalam departemen keuangan. Kebanyakan perusahaan tidak memiliki departemen akuntansi manajemen, dan karena itu akuntansi manajemen tidak berperan besar dalam manajemen perusahaan. [6] Akhirnya, akuntan sendiri kurang memperhatikan akuntansi manajemen yang hanya dipahami sebagai membuat akun. Perkembangan yang kuat dari Internet telah membawa serangkaian bisnis baru seperti Tencent QQ, Red Envelope dan WeChat Beruntung Uang. Jika kita gagal untuk menyadari pentingnya akuntansi manajemen, kita tidak akan dapat memberikan akuntansi dukungan teori untuk bisnis baru. Perkembangan yang kuat dari Internet telah membawa serangkaian bisnis baru seperti Tencent QQ, Red Envelope dan WeChat Beruntung Uang. Jika kita gagal untuk menyadari pentingnya akuntansi manajemen, kita tidak akan dapat memberikan akuntansi dukungan teori untuk bisnis baru. Perkembangan yang kuat dari Internet telah membawa serangkaian bisnis baru seperti Tencent QQ, Red Envelope dan WeChat Beruntung Uang. Jika kita gagal untuk menyadari pentingnya akuntansi manajemen, kita tidak akan dapat memberikan akuntansi dukungan teori untuk bisnis baru.

\section{Keuntungan dari aplikasi praktis dari Big Data tanpa diambil}

Dengan munculnya era informasi, Big Data telah dikenal oleh berbagai perusahaan dan secara bertahap diadopsi. Namun, dalam kerja praktek, bagaimana Big Data dapat dikombinasikan dengan akuntansi manajemen untuk membuat aplikasi nyata dan mengembangkan perusahaan masih tetap lemah link dari banyak perusahaan. Alasannya adalah bahwa perusahaan memiliki tidak pemahaman yang benar tentang aplikasi spesifik Big Data, juga tidak mengembangkan teknik untuk Big Data dan aplikasi akuntansi manajemen, yang mengarah ke satu sisi pemahaman sehingga mempengaruhi pengembangan keseluruhan operasi perusahaan. Terutama untuk usaha kecil dan menengah yang biaya modal relatif terbatas, jika mereka tidak bisa menilai situasi pasar benar tetapi membabi buta memperluas produksi dan berinvestasi dalam peralatan dan mesin, sangat merugikan produksi profesional mereka. Oleh karena itu, aplikasi praktis dari akuntansi manajemen di bawah pengaruh Big Data ini diperlukan untuk seluruh operasi perusahaan. Perusahaan harus terlebih dahulu membuat jelas arah pembangunan mereka dan tujuan, dan kemudian 
menggabungkan kelebihan dari Big Data dan akuntansi manajemen untuk memandu operasi keseluruhan perusahaan, sehingga membuat keputusan yang lebih baik dan penilaian untuk perusahaan.

\section{Kebanyakan personil akuntansi tidak memiliki keterampilan komputer di era "Internet Plus"}

Di satu sisi, dengan latar belakang pengembangan "Internet Plus", pesatnya perkembangan teknologi informasi dan data ekonomi yang semakin kompleks di marketlead kesulitan analisis data keuangan perusahaan dan pengolahan. Beberapa perusahaan di Indonesia, bagaimanapun, sering menggunakan cara yang paling primitif dan tidak efisien secara manual memeriksa buku-buku dan indikator keuangan masukan dalam proses pengolahan data keuangan, yang tidak hanya akan mempengaruhi efisiensi analisis keuangan perusahaan, tetapi juga menyebabkan penyimpangan data dan mengurangi manfaat perusahaan. Di sisi lain, sementara bakat akuntansi di Indonesia telah mencapai titik jenuh, akuntan yang benar-benar memiliki keterampilan komputer high-end jarang terjadi. Dengan kedatangan era "Internet Plus", pemutusan antara ilmu komputer dan akuntansi disiplin telah menyebabkan munculnya "high-end bakat kekurangan" dalam akuntansi manajemen. Dalam rangka untuk beradaptasi dengan ICT akuntansi di bawah era Internet, perlu untuk memperkuat pelatihan komputerisasi akuntansi untuk tenaga akuntansi dan mengolah dan membentuk tim manajemen yang tahu tentang kedua keuangan dan bisnis.

\section{Sistem keamanan informasi yang relatif lengkap di perusahaan}

Sebagai suatu perusahaan, informasi yang jelas secara real time adalah kunci untuk pengembangan lebih lanjut. Informasi data dengan analisis yang efektif dan penyortiran ini sangat berguna. Semakin rinci proses analisis, semakin besar kemungkinan aplikasi praktis bagi perusahaan. Informasi kunci mencakup informasi pelanggan perusahaan, riset pasar dan pengembangan masa depan yang sangat penting untuk pengambilan keputusan. Manajemen keamanan informasi yang disebutkan di atas adalah sangat penting karena sekali bocor ke rekan-rekan, hilangnya internal perusahaan tidak diragukan lagi besar.

Secara khusus, aplikasi yang efektif dari Internet membuat manajemen keamanan informasi di perusahaan-perusahaan yang sangat tidak menguntungkan, dan penggunaan staf dan isu-isu lain membuatnya lebih buruk. Oleh karena itu, perusahaan dituntut untuk memperkuat manajemen internal mereka dan mempromosikan sistem keamanan informasi, yang dapat dikaitkan dengan aplikasi praktis dari akuntansi manajemen dengan staf profesional yang sangat baik dan sikap kerja teliti untuk memastikan pertambangan dalam informasi perusahaan dan mencapai manajemen keamanan. Solusi untuk pengembangan akuntansi manajemen dalam era "Internet Ditambah akuntansi" Ini adalah pengaruh "Internet Ditambah akuntansi" yang membuat akuntansi manajemen menghadapi banyak peluang dan tantangan. Dalam situasi ini lebih menekankan pada akuntansi manajemen dan akuntansi manajemen mempromosikan oleh platform informasi Internet. 


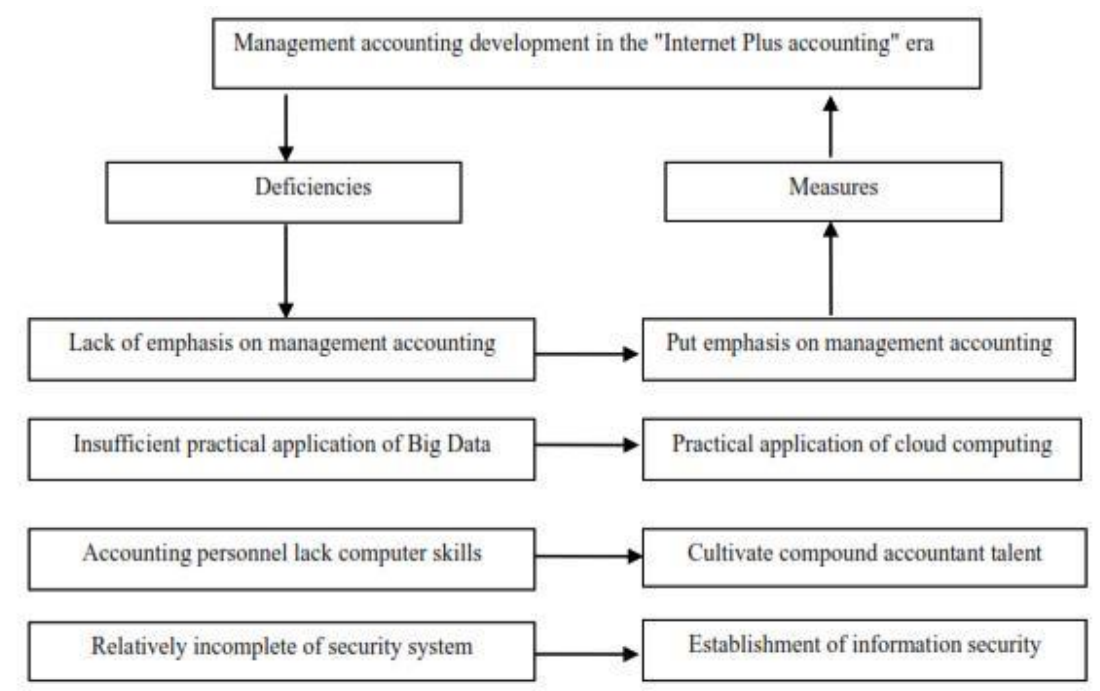

Gambar 1. Kerangka pembangunan akuntansi manajemen di era "Internet Ditambah akuntansi"

Pertama, organisasi akuntansi harus menetapkan asosiasi akuntansi manajemen dan memperkuat pertukaran internasional dan kerjasama dalam akuntansi manajemen untuk secara aktif menyerap prestasi budaya manajemen yang canggih akuntansi luar negeri. Kedua, tingkat manajemen perusahaan harus lebih mementingkan akuntansi manajemen, membuat tenaga kerja divisionof jelas antara akuntansi manajemen dan akuntansi keuangan. Usaha harus memiliki afull-waktu departemen akuntansi manajemen dan menawarkan fungsi independen. Lebih emphasisshould diletakkan pada studi kasus yang khas serta hubungan antara teori dan praktek. Whileactively mendapatkan pengalaman dari perusahaan yang berpengalaman, perusahaan juga harus memberikan tomanagement bermain penuh akuntansi dalam manajemen perusahaan.

Sistem manajemen insentif kompensasi terus ditingkatkan untuk menciptakan lingkungan yang menguntungkan bagi pengembangan akuntansi manajemen internal. Sementara itu, perusahaan harus dilengkapi dengan Big Data berpikir, memperkuat aplikasi dan promosi alat manajemen modern seperti berbagi keuangan model pusat, pengadaan awan, berbagi awan dan layanan cloud manajemen biaya. Terakhir, personel akuntansi harus mengintegrasikan dengan pemikiran "Internet Plus" dan beradaptasi dengan arah pengembangan umum industri dalam era "Internet Plus".

\section{Aplikasi praktis dari teknologi komputasi awan}

Aplikasi praktis dari teknologi cloud computing adalah inti dari aplikasi Big Data. Dalam akuisisi informasi saat ini, data mentah tanpa diolah diperoleh dan menerapkannya langsung ke produksi dan bagian penjualan bisa sangat berisiko karena akurasi dan rasionalitas mereka tidak dijamin. teknologi cloud computing adalah proses menganalisis dan memilah data, yang mengurangi biaya waktu dan memperkuat pengolahan efektif data pada saat yang sama, membuat untuk kelemahan dari teknologi analisis informasi data yang tidak akurat. Terutama, transformasi informasi dalam komputasi awan langsung transfer data mentah ke informasi yang efektif memenuhi kebutuhan akuntansi manajemen melalui bimbingan teknis aplikasi.

\section{Meningkatkan kualitas akuntan dan budidaya akuntan senyawa}

Dalam industri akuntansi di bawah era "Internet Plus", fungsi akuntansi telah berubah dari akuntansi manajemen. Di satu sisi, perusahaan harus penuh semangat memperkenalkan personil akuntansi manajemen high-end. Di sisi lain, mereka harus lebih mementingkan transformasi dan budidaya personil akuntansi internal. Perusahaan harus membuat penuh 
penggunaan internet dan sarana media modern lainnya, mengadopsi modus "Internet Ditambah mengajar" untuk melanjutkan pendidikan tenaga akuntansi untuk meningkatkan kemampuan manajemen mereka dan menumbuhkan akuntan senyawa. Seminar akademik akuntansi harus dilakukan secara berkala untuk terus meringkas pengalaman akuntansi manajemen, dan meningkatkan kemampuan manajemen personil akuntansi. Akuntansi pelatihan komputerisasi untuk akuntan harus diperkuat untuk beradaptasi dengan persyaratan baru dari ICT akuntansi di bawah era "Internet Plus". Sementara itu, personil akuntansi harus didorong untuk belajar tentang disiplin baru termasuk pengetahuan tentang audit internal, keuangan perusahaan dan aspek lain untuk memperluas cakrawala mereka. Untuk personil akuntansi, upgrade pengetahuan dan pemikiran sesuai dengan arah umum dari industri dalam era "Internet Plus", dan juga satu-satunya cara untuk meningkatkan nilai mereka sendiri. keuangan perusahaan dan aspek-aspek lain untuk memperluas cakrawala mereka. Untuk personil akuntansi, upgrade pengetahuan dan pemikiran sesuai dengan arah umum dari industri dalam era "Internet Plus", dan juga satu-satunya cara untuk meningkatkan nilai mereka sendiri. keuangan perusahaan dan aspek-aspek lain untuk memperluas cakrawala mereka. Untuk personil akuntansi, upgrade pengetahuan dan pemikiran sesuai dengan arah umum dari industri dalam era "Internet Plus", dan juga satu-satunya cara untuk meningkatkan nilai mereka sendiri.

\section{Pembentukan sistem keamanan informasi}

Seperti disebutkan di atas, keamanan informasi memiliki dampak tertentu pada pengembangan usaha, sehingga jaminan keamanan informasi sangat penting. Ini mensyaratkan bahwa perusahaan harus memiliki langkah-langkah manajemen yang sesuai seperti aplikasi yang sangat baik dari teknologi jaringan dan manajemen. Setelah perilaku seperti pemalsuan dan kebocoran terjadi, mereka dapat dikenal di tempat pertama sehingga keputusan yang sesuai dapat dibuat. Selain itu, banyak perusahaan tidak mampu untuk membangun perpustakaan pengolahan data informasi mereka sendiri karena faktor-faktor seperti pengembangan diri mereka. Dalam situasi ini, perusahaan dengan hati-hati perlu memeriksa perusahaan lain tingkat pelayanan, tingkat bisnis dan faktor lainnya, membawa pada kontrol kualitas yang ketat untuk meminimalkan risiko.

\section{KESIMPULAN DAN SARAN}

Singkatnya, di era "Internet Plus", akuntansi manajemen memiliki peluang pengembangan dan pada saat yang sama bertemu tantangan utama. "Internet Plus" telah memberikan dasar yang baik bagi pengembangan manajemen akuntansi dan mengubah cara berpikir. Menghadapi Data numerouscomplicated, manajemen personil akuntansi dapat mengumpulkan, menganalisis, mengolah dan memanfaatkan informasi data yang relevan dengan bantuan komputasi awan, yang menyediakan dukungan kuat untuk prediksi, pengambilan keputusan, analisis dan penilaian. Big Data memiliki. dipromosikan pengembangan akuntansi manajemen, tetapi perusahaan, perguruan tinggi dan universitas harus mengidentifikasi peluang dan tantangan yang dihadapi oleh itu, aktif belajar Big Data dan terus beradaptasi dengan era "Internet Plus" sehingga untuk mewujudkan penggunaan yang efektif dari "Internet Plus" dalam akuntansi manajemen. 


\section{DAFTAR RUJUKAN}

"Penilaian ERP status fungsional di lobus temporal: Meneliti berkorelasi spatiotemporal dari pengenalan obyek". Mazerolle EL. International Journal Of psikofisiologi: Jurnal Resmi Of The International Organization Of psikofisiologi. 2007

"Investigasi keberhasilan sistem ERP: Studi kasus di tiga industri teknologi tinggi Taiwan". Chien, Shih-Wen, Tsaur-Ming. Komputer di Industri. 2007

Kinerja manajemen: sebuah kerangka kerja untuk penelitian sistem pengendalian manajemen. David Otley. Akuntan manajemen. 1999

Pengetahuan chain [J]. Richard A. Spinello. Horizons bisnis. 1998

Pengetahuan manajemen: agenda strategis [J]. Paul Quintas, Paul Lefere, Geoff Jones. Panjang Perencanaan Range. 1997 